\title{
Localization of the murine cholecystokinin A and $B$ receptor genes
}

\author{
L.C. Samuelson, M.S. Isakoff, K.A. Lacourse \\ Department of Physiology, University of Michigan, 7761 Medical Science II, Ann Arbor, Michigan 48109-0622, USA
}

Received: 30 August 1994 / Accepted: 14 December 1994

\begin{abstract}
We have determined the chromosomal locations of the two cholecystokinin (CCK) receptor genes in the mouse. Genetic localization utilized an interspecific backcross panel formed from the cross (C57BL/6J $\times$ Mus spretus) $\mathrm{F}_{1} \times$ Mus spretus. Genomic DNAs from 94 individuals in the backcross were analyzed by Southern hybridization with rat $\mathrm{CCK}_{\mathrm{A}}$ and $\mathrm{CCK}_{\mathrm{B}}$ receptor cDNA probes. Unique map positions were determined by haplotype analysis with 650 previously mapped loci in the mouse backcross. The $\mathrm{CCK}_{\mathrm{A}}$ receptor gene (Cckar) mapped to mouse Chromosome (Chr) 5, in tight linkage with the DNA marker D5Bir8. The $\mathrm{CCK}_{\mathrm{B}}$ receptor gene ( $C c k b r)$ mapped to mouse $\mathrm{Chr} 7$, tightly linked to the $\beta$-hemoglobin locus $(H b b)$. This localization places $C c k b r$ in the same region as the mouse obesity mutation tubby $(t u b)$, which also maps near $H b b(2.4 \pm 1.4 \mathrm{cM})$. Since CCK can function as a satiety factor when administered to rodents, localization of $C c k b r$ near the tub mutation identifies this receptor as a possible candidate gene for this obesity mutation.
\end{abstract}

\section{Introduction}

The peptide hormone cholecystokinin (CCK) is one of a group of gut/brain peptides that have distinct processes in the central nervous system and the gastrointestinal system. CCK regulates many digestive functions, including stimulation of pancreatic enzyme secretion and gallbladder contraction, as well as gastric motility. $\mathrm{CCK}$ has also been demonstrated to act as a satiety factor capable of reducing food intake. This effect appears to operate both peripherally, through the vagus nerve, and centrally, by unknown mechanisms (Gibbs et al. 1973; Gibbs and Smith 1986; Smith et al. 1985). The functions ascribed to CCK suggest that it may coordinate peripheral and central processes regulating digestion and feeding behavior. Thus, CCK and its receptors are potential factors involved in the genesis of obesity.

There are two distinct G-protein-coupled receptors for CCK that differ in agonist and antagonist binding characteristics. The $\mathrm{CCK}_{\mathrm{A}}$ receptor predominates in the gastrointestinal tract and has been demonstrated to mediate pancreatic enzyme secretion and gallbladder contraction (Jenson et al. 1989). The $\mathrm{CCK}_{\mathrm{B}}$ receptor predominates in the brain (Innis and Snyder 1980), and specific antagonist experiments indicate its involvement in anxiety and analgesia (Wiesenfeld-Hallin et al. 1990; Dourish et al. 1990; Hughes et al. 1990; Singh et al. 1991). CCK receptor cDNA clones have recently been isolated for both the A-type receptor (Wank et al. 1992a; de Weerth et al. 1993; Ulrich et al. 1993) and the B-type receptor (Wank et al. 1992b; Pisegna et al. 1992; Nakata et al. 1992; Lee et al. 1993; Kopin et al. 1992). Molecular characterization of the $\mathrm{CCK}_{\mathrm{B}}$ receptor has demonstrated that it is also the receptor for the related peptide gastrin (Wank et al. 1992b; Lee et al. 1993).

The diverse biological activities of CCK indicate that it or its

Correspondence to: L.C. Samuelson receptors could be involved in a number of human pathologies, including obesity, gastrointestinal disorders, and mental health. To investigate the possible involvement of these genes in obesity syndromes, we studied their genetic locations in the mouse. Several mouse mutants have been described with single gene mutations leading to obesity, including: yellow $(A)$, diabetes $(d b)$, obese $(o b)$, tubby $(t u b)$, adipose $(A d)$, and fat ( fat) (reviewed in Friedman et al. 1991). Localization of the mouse CCK gene to Chr 9 excluded the involvement of the CCK peptide in these mutations, located on Chrs 2, 4, 6, 7, and 8 . In this study we have mapped the genetic locations of the two CCK receptor genes. Our data demonstrate that the $\mathrm{CCK}_{\mathrm{A}}$ receptor gene is on mouse $\mathrm{Chr} 5$, within an extensive domain of synteny homology with human $\mathrm{Chr} 4$. The $\mathrm{CCK}_{\mathrm{B}}$ receptor gene mapped to mouse $\mathrm{Chr} 7$, in the same region as the spontaneous obesity mutation $t u b$. Localization to this region of Chr 7, together with the known satiety function of CCK, identifies the $\mathrm{CCK}_{\mathrm{B}}$ receptor as a viable candidate gene for the tubby mutation.

\section{Materials and methods}

CCK receptor hybridization probes. The mouse CCK receptor genes were detected by Southern hybridization analysis with probes prepared from rat cDNAs (cDNA clones were generously provided by Stephen Wank, National Institutes of Health). The $\mathrm{CCK}_{\mathrm{A}}$ receptor probe was a $1.3 \mathrm{~kb}$ fragment that included the complete coding region (nucleotides 154-1487; Wank et al. 1992a). Two $\mathrm{CCK}_{\mathrm{B}}$ receptor probes were utilized. A full-length rat cDNA probe (Wank et al. 1992b) was used for characterization of the $\mathrm{CCK}_{\mathrm{B}}$ receptor gene structure in tubby mice. Genetic mapping of the $\mathrm{CCK}_{\mathrm{B}}$ receptor in the interspecific backcross utilized a 474 bp cDNA fragment (nucleotides 136-610) generated by polymerase chain reaction (PCR) amplification with the following primers: CKB5 (5' ACTCTAGAATGGAGCTGCTCAAGCTGAACC; underlined bases indicate the ATG start codon) and CKA/BA (5'ATATCGATGTCGGCAGATGGCGCTATATC). PCR reactions contained $10 \mathrm{~mm}$ Tris- $\mathrm{HCl}$, $\mathrm{pH} \mathrm{8.3;50}$ $\mathrm{mM} \mathrm{KCl} ; 4 \mathrm{~mm} \mathrm{MgCl} ; ; 0.01 \%$ (wt/vol) bovine serum albumin; $0.02 \mathrm{~mm}$ of dATP, dCTP, dGTP, and dTTP (Pharmacia); $0.2 \mu \mathrm{M}$ of each primer (University of Michigan Oligonucleotide Synthesis Facility); and Taq polymerase. After initial denaturation at $94^{\circ} \mathrm{C}$ for $1.5 \mathrm{~min}$, samples were amplified with 35 cycles of $92^{\circ} \mathrm{C}$ for $0.5 \mathrm{~min}, 55^{\circ} \mathrm{C}$ for $0.5 \mathrm{~min}, 72^{\circ} \mathrm{C}$ for $1.5 \mathrm{~min}$, followed by incubation at $72^{\circ} \mathrm{C}$ for 4 min.

DNA fragments used for Southern hybridization probes were isolated from low-melt agarose gels using the Qiaex Gel Extraction Kit as directed by the manufacturer (Qiagen Inc., Chatsworth, Calif.). Purified DNA fragments were ${ }^{32} \mathrm{P}$-labeled by the random oligonucleotide primer method (Feinberg and Vogelstein 1983), followed by centrifugation through a Sephadex G-50 spin column. Before addition to the hybridization reaction, ${ }^{32}$ P-labeled probes were denatured by boiling for $10 \mathrm{~min}$, followed by cooling to $0^{\circ} \mathrm{C}$.

Southern blot analysis for characterization of RFLPs. C57BL/6J, Mus spretus, and tub/tub genomic DNAs were purchased from The Jackson Laboratory (Bar Harbor, Me.) or provided by Sally Camper (University of Michigan). Restriction enzyme digests contained $10 \mu \mathrm{g}$ of DNA and 25 units of enzyme, in buffers recommended by the enzyme manufacturer, with the addition of $4 \mathrm{~mm}$ spermidine. After electrophoresis in $0.7 \%$ aga- 
rose gels with TAE buffer ( $40 \mathrm{~mm}$ Tris-acetate, $1 \mathrm{~mm}$ EDTA, $\mathrm{pH}$ 7.4), DNAs were transferred to Zetaprobe nylon membrane according to the capillary transfer protocol recommended by the manufacturer (BioRad). Filters were hybridized with ${ }^{32} \mathrm{P}-1$ labeled rat CCK receptor probes at $60^{\circ} \mathrm{C}$ in hybridization solution containing $0.5 \mathrm{M}$ Na-phosphate buffer, $\mathrm{pH} 7.2,1$ mM EDTA, 7\% SDS, and $100 \mu \mathrm{g} / \mathrm{ml}$ denatured salmon sperm DNA. The final wash solution consisted of $1 \times \mathrm{SSC}(0.15 \mathrm{M} \mathrm{NaCl}, 15 \mathrm{~mm}$ trisodium citrate, $\mathrm{pH} 7.0$ ) and $0.1 \%$ SDS. Hybridization band patterns were detected by autoradiography with Kodak XAR-5 film and an FBIS 810 intensifying screen (FisherBiotech).

Southern analysis of backcross panel DNAs. DNA isolated from 94 progeny from the cross (C57BL/6J $\times M$. spretus) $\mathrm{F}_{1} \times M$. spretus (BSS) were provided by The Jackson Laboratory. This well-characterized backcross panel included 650 typed loci at the time of this study (Rowe et al. 1994; L. Rowe, personal communication). The backcross DNAs were digested with $\mathrm{Xba} \mathrm{I}$ in microtiter plates incubated at $37^{\circ} \mathrm{C}$ in a MJ Research thermocycler. Digested DNAs were subjected to agarose gel electrophoresis in TAE buffer and transferred to Zetaprobe membranes by the alkaline transfer method recommended for analysis of the backcross panel by The Jackson Laboratory. Before Southern hybridization with ${ }^{32} \mathrm{P}$-labeled CCK receptor probes, the membranes were washed twice for $10 \mathrm{~min}$ in 0.1 $\times$ SSC, $0.5 \%$ SDS at $65^{\circ} \mathrm{C}$, followed by washing at room temperature for $20 \mathrm{~min}$ in $0.2 \times \mathrm{SSC}, 0.2 \%$ SDS (preheated to $95^{\circ} \mathrm{C}$ ). Southern hybridization of the filters with ${ }^{32} \mathrm{P}$-labeled rat CCK receptor cDNA probes was performed as described above.

PCR typing D7Mit37 (Hbb). The mouse $\beta$-hemoglobin locus $(H b b)$ was mapped in the BSS backcross by typing for the D7Mit37 DNA simple sequence length polymorphism. The D7Mit37 marker is contained within the $\beta$-hemoglobin locus in the locus activating region (Dietrich et al. 1994). The D7Mit37 primers (5'CCTAGAAGCAACAGAATCACACA and 5'CAGGTCAGATAAGGAAACAGGG; Research Genetics) amplify a region containing a dinucleotide repeat which is polymorphic between $M u s$ spretus and C57BL/6J. PCR reaction were modified from the method described above by using reaction buffer containing $1.5 \mathrm{mM} \mathrm{MgCl} 2$, under the following conditions: (i) denaturation at $94^{\circ} \mathrm{C}$ for $3 \mathrm{~min}$; (ii) 40 cycles of $94^{\circ} \mathrm{C}$ for $0.5 \mathrm{~min}, 60^{\circ} \mathrm{C}$ for $1 \mathrm{~min}, 72^{\circ} \mathrm{C}$ for $1 \mathrm{~min}$; (iii) incubation at $72^{\circ} \mathrm{C}$ for $5 \mathrm{~min}$. The 162 bp C $57 \mathrm{BL} / 6 \mathrm{~J}$ fragment was separated from the $180 \mathrm{bp} \mathrm{M}$. spretus fragment by electrophoresis in $3 \%$ wide range/standard 3:1 agarose (Sigma Chemical Co., St. Louis, Mo.).

Statistical analysis of mapping data. Estimated distances between loci were calculated by dividing the number of recombinants between two loci by the total number of individuals typed at those loci. Standard errors were calculated by taking the square root of $r(1-r) / n$, where $r$ is the recombination frequency and $n$ is the number of possible recombinant chromosomes. The estimated maximum recombination distance for two nonrecombinant loci was calculated with the formula $P=(1-r)^{n}$, where $P$ is the probability, $r$ is the maximum recombination frequency, and $n$ is the number of individuals examined (Dizik and Elliott 1977). At the 95\% confidence level, the calculated maximum distance between nonrecombinant loci typed for the 94 individuals in the BSS panel is $3.1 \mathrm{cM}$.

\section{Results}

Southern Characterization of mouse CCK receptor genes. Southern analysis was performed on genomic DNA from mouse strains C57BL/6J and Mus spretus to identify strain-specific differences in the pattern of hybridization with CCK receptor probes. Genomic DNAs were digested with seven different restriction enzymes, and Southern analysis was performed with rat CCK receptor cDNA probes. The sizes of hybridizing $\mathrm{CCK}$ receptor gene fragments were determined by comparison of migration distances with a molecular weight standard on the same gel. Four restriction enzymes (BamHI, EcoRI, HindIII, and ScaI) yielded identical hybridization patterns in the domestic strain C57BL/6J and the wild strains Mus spretus (Fig. 1 and data not shown). Three digests (Pst I, $S a c$ I, and $X b a$ I) demonstrated polymorphic fragments for both the $\mathrm{CCK}_{\mathrm{A}}$ receptor and $\mathrm{CCK}_{\mathrm{B}}$ receptor probes (Fig. 1 and Table
A.

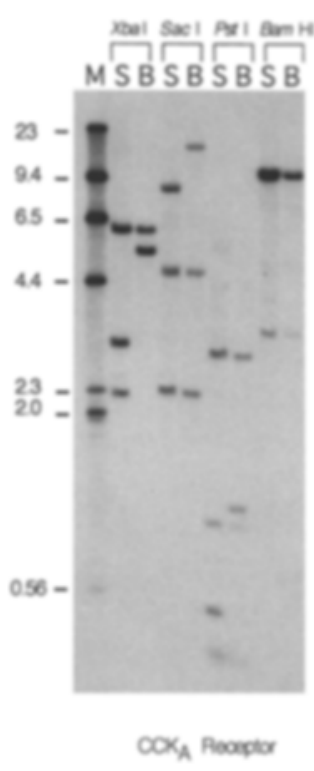

B.

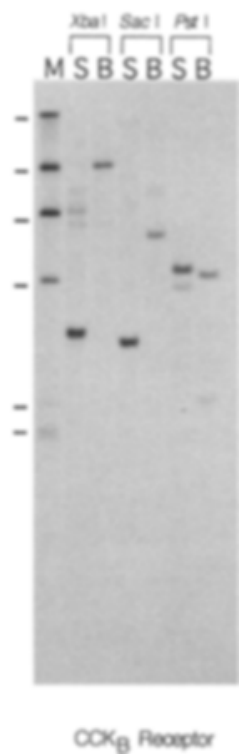

Fig. 1. Mouse CCK receptor gene polymorphisms in two mouse strains. Southern hybridization analysis of the mouse $\mathrm{CCK}_{\mathrm{A}}$ receptor gene $(\mathrm{A})$ and the $\mathrm{CCK}_{\mathrm{B}}$ receptor gene (B) in the wild mouse strain Mus spretus (S) and the domestic inbred strain C57BL/6J (B). Genomic DNAs were digested with the restriction enzymes shown and subjected to Southern analysis with rat CCK receptor $\mathrm{cDNA}$ probes. The $1.3-\mathrm{kb}^{\mathrm{CCK}} \mathrm{A}$ receptor probe contained the complete coding region of the gene. The $0.47-\mathrm{kb} \mathrm{CCK}_{B}$ receptor probe included the $5^{\prime}$ end of the cDNA. The sizes $(\mathrm{kb})$ of the molecular weight standard $\lambda \times \operatorname{HindIII}(\mathrm{M})$ are indicated on the left

1). The restriction enzyme $X b a I$ yielded easily distinguished polymorphisms between the two parental strains and was chosen to type an interspecific backcross to map the two CCK receptor genes in the mouse.

Genetic localization of the mouse $C C K_{A}$ receptor gene. An interspecific backcross panel formed from the BSS cross $(\mathrm{C} 57 \mathrm{BL} / 6 \mathrm{~J} \times$ $M$. spretus) $\mathrm{F}_{1} \times M$. spretus was tested for the inheritance of $C c k a r$ alleles. DNA samples were digested with $X b a \mathrm{I}$ and subjected to Southern hybridization analysis. Samples were typed for the inheritance of the C57BL/6J (B) or spretus (S) alleles after hybridization with a $\mathrm{CCK}_{\mathrm{A}}$ receptor cDNA probe. The probe detected two fragments unique to $M$. spretus, $3.4 \mathrm{~kb}$ and $2.3 \mathrm{~kb}$ in size, a $5.6 \mathrm{~kb}$ fragment unique to $\mathrm{C} 57 \mathrm{BL} / 6 \mathrm{~J}$, and a $6.4-\mathrm{kb}$ fragment common to both strains (Fig. 1A and Table 1). The inheritance of B or $S$ alleles in the panel was determined by scoring the 94 backcross DNAs for the presence (B) or absence (S) of the $5.6 \mathrm{~kb}$ fragment unique to $\mathrm{C} 57 \mathrm{BL} / 6 \mathrm{~J}$. We established the unambiguous gene order

Table 1. CCK receptor gene polymorphisms between C57BL/6J and Mus spretus detected by Southern analysis. Fragment sizes observed after hybridization of mouse genomic DNAs with a $1.3-\mathrm{kb}$ rat $\mathrm{CCK}_{\mathrm{A}}$ receptor $\mathrm{CDNA}$ probe $(\mathrm{A})$ or a $0.47-\mathrm{kb}$ rat $\mathrm{CCK}_{\mathrm{B}}$ receptor $\mathrm{CDNA}$ probe $(\mathrm{B})$ are listed in kilobases. Hybridizing $\mathrm{CCK}$ receptor gene fragments which are polymorphic between the two strains are underlined.

\begin{tabular}{llll}
\hline A. CCK $_{\mathbf{A}}$ receptor: & Enzyme & C57BL/6J & Mus spretus \\
\hline & Pst I & $2.9,1.0,0.93,0.36$ & $2.9,0.93, \underline{0.5}, 0.36$ \\
& Sac I & $\underline{18.0}, 4.9, \underline{1.9}$ & $\underline{8.8}, 4.9, \frac{2.3}{6.4}, \underline{3.4}, \frac{2.3}{2}$ \\
\hline Xba I & $6.4, \underline{5.6}$ & Mus spretus \\
\hline B. CCK $\mathbf{B}$ receptor: & Enzyme & C57BL/6J & $\frac{4.7}{3.2}$ \\
\hline & Pst I & $\frac{4.6}{5.7}$ & $\underline{3.3}$ \\
\hline
\end{tabular}


on the basis of haplotype analysis (Fig. 2). The intergenic distances (cM) were determined for Cckar relative to other markers in the data set. The map position of Cckar with respect to five markers on Chr 5 are shown (Fig. 2); 33 additional loci on Chr 5 are not shown. The marker D5Bir8 segregated with Cckar without recombination $(0 / 91)$.

Genetic localization of the mouse $C C K_{B}$ receptor gene. Southern blots of $X b a I$-digested backcross DNA samples were hybridized with the rat $\mathrm{CCK}_{\mathrm{B}}$ receptor cDNA probe to determine the pattern of inheritance of the parental alleles. The probe detected a $3.3 \mathrm{~kb}$ fragment in $M$. spretus DNA and a $9.6 \mathrm{~kb}$ fragment in C57BL/6J DNA (Fig. 1B and Table 1). Thus, the inheritance of $B$ or $S$ alleles in the backcross progeny was determined by scoring for the presence (B) or absence (S) of the $9.6 \mathrm{~kb}$ fragment unique to C57BL/ 6J. We established the unambiguous gene order on Chr 7 on the basis of haplotype analysis (Fig. 3).

The mouse $\mathrm{CCK}_{\mathrm{B}}$ receptor gene mapped to the same region as the previously described obesity mutation tubby, which is known to be closely linked to $H b b(2.4 \pm 1.4 \mathrm{cM}$; Jones et al. 1992). Therefore, we determined the linkage of $C c k b r$ to $H b b$ by typing the BSS backcross panel for the polymorphic DNA marker D7Mit37, which lies within the $\beta$-hemoglobin locus (Dietrich et al. 1994). PCR amplification with D7Mit37 primers yielded DNA fragments of $162 \mathrm{bp}$ from C57BL/6J and $180 \mathrm{bp}$ from Mus spretus (not shown). Typing the BSS backcross panel for D7Mit37 demonstrated tight linkage to $C c k b r$, with no recombinants (0/94). The intergenic distances (cM) were determined, and standard error was calculated for $\mathrm{Cckbr}$ and five other markers on Chr 7 (Fig. 3). The relationship between $C c k b r$ and 35 additional loci on $\mathrm{Chr} 7$ is not shown.

Cckbr gene structure is unchanged in tub/tub mice. The tubby obesity mutation arose spontaneously in a C57BL/6J mouse (Coleman and Eicher 1990). The genetic localization of $C c k b r$ close to $\mathrm{Hb} b$ on mouse Chr 5 indicated that it could be a candidate gene for the tub mutation. We tested whether the structure of the $\mathrm{CCK}_{\mathrm{B}}$ receptor gene was altered in $t u b / t u b$ mice by genomic Southern

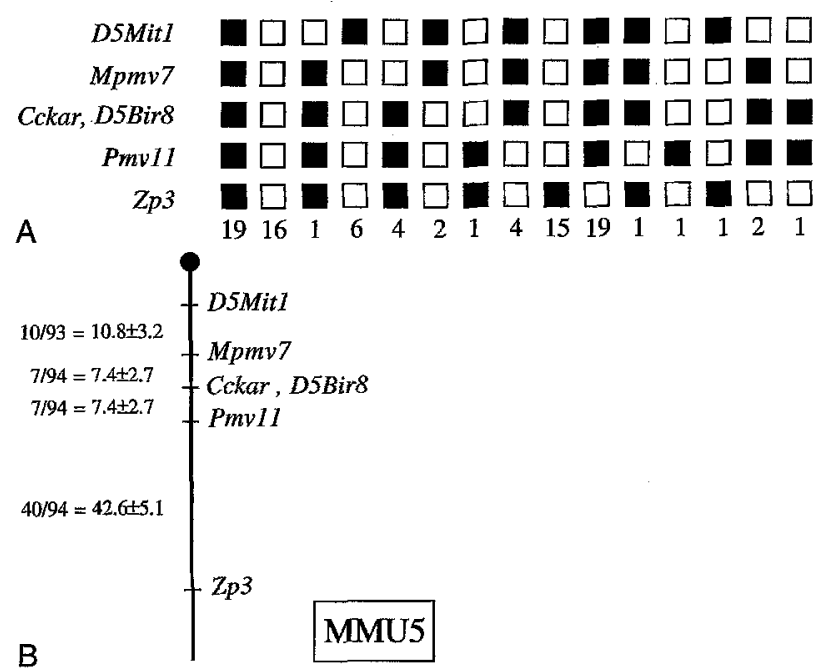

Fig. 2. Genetic localization of the $\mathrm{CCK}_{\mathrm{A}}$ receptor gene on mouse $\mathrm{Chr} 5$. (A) Haplotype distribution of 93 individuals in the BSS backcross. Each column represents a chromosomal haplotype with the number of animals observed with that haplotype given below. Animals were scored at each locus as heterozygous for the $M$. spretus and C57BL/6J alleles (filled boxes) or homozygous for the M. spretus alleles (open boxes). (B) Genetic map of Chr 5 constructed from the haplotype distribution in part A. The map distances, in $\mathrm{cM}$, were calculated from the recombination frequency observed for each interval (left).

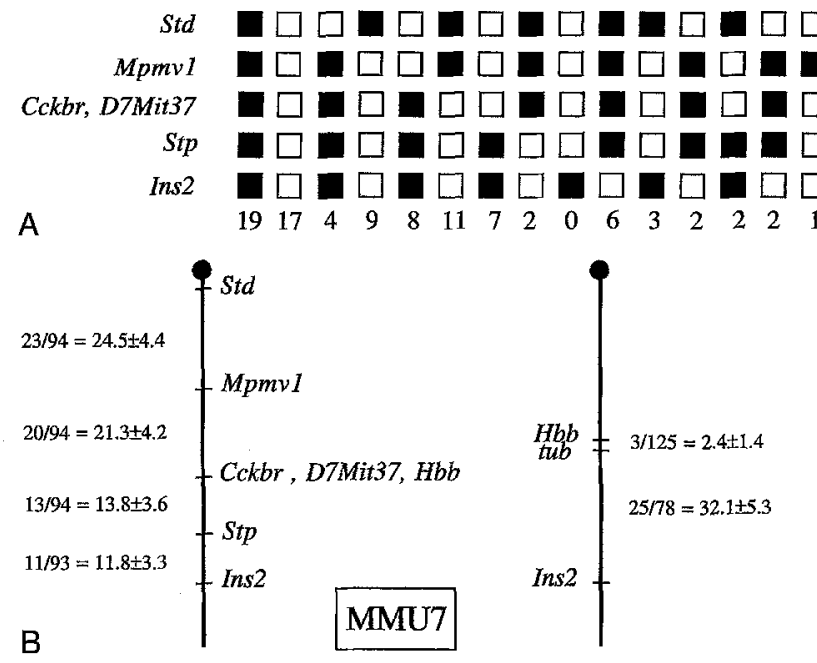

Fig. 3. Genetic localization of the $\mathrm{CCK}_{\mathrm{B}}$ receptor gene on mouse Chr 7 . (A) Haplotype distribution of 93 individuals in the BSS backcross. Each column represents a chromosomal haplotype with the number of animals with the haplotype given below. Animals were scored at each locus as beterozygous for the $M$. spretus and C57BL/6J alleles (filled boxes) or homozygous for the $M$. spretus alleles (open boxes). (B) A genetic map of $\mathrm{Chr} 7$ constructed from the haplotype distribution in part $\mathrm{A}$ is shown on the left. This map is compared with a linkage map constructed from tubby backcross studies (right). The $H b b$ locus is included in the linkage map generated from the BSS backcross because of its known genetic association with D7Mit37. The tubby data are from Coleman and Eicher (1990) and Jones and associates (1992).

analysis with ten different restriction enzymes and probing with a full-length $\mathrm{CCK}_{\mathrm{B}}$ receptor cDNA probe. The hybridization patterns were identical in $t u b / t u b$ and C57BL/6J DNA (Fig. 4). Thus, tubby is not the result of a large deletion, insertion, or rearrangement in the $\mathrm{CCK}_{\mathrm{B}}$ receptor gene.

\section{Discussion}

We determined the genetic locations of the murine $\mathrm{CCK}_{\mathrm{A}}$ receptor and $\mathrm{CCK}_{\mathrm{B}}$ receptor genes by analysis of an interspecific backcross of Mus spretus and Mus musculus (C57BL/6J). Parental spretus and $\mathrm{C} 57 \mathrm{BL} / 6 \mathrm{~J}$ alleles were typed in the 94 individuals in this backcross panel by Southern hybridization analysis with rat $\mathrm{CCK}$ receptor cDNA probes. Genetic positions were determined relative to 650 previously mapped loci in the panel. Our results show that these two genes are genetically unlinked and map to distinct mouse chromosomes. The murine map positions follow mouse:human synteny homology relationships predicted from the chromosomal locations of the human CCK receptor genes. The $\mathrm{CCK}_{\mathrm{A}}$ receptor gene was mapped to human $\mathrm{Chr} 4$ by somatic cell hybrid analysis (de Weerth et al. 1993; Samuelson and Isakoff, data not shown). The mouse Cckar gene mapped within a $35 \mathrm{cM}$ block of genes on mouse Chr 5, which localize to Chr 4p15-16 in the human (Kozak and Stephenson 1993). Thus, the map position of Cckar in the mouse predicts that the human gene will be regionally localized to Chr 4p15-16.

The $\mathrm{CCK}_{\mathrm{B}}$ receptor gene mapped to mouse Chr 7, within a group of genes that have been mapped to human Chr 11 (Holdener et al. 1993). This region of homology between human Chr 11 and mouse Chr 7 stretches from $T y r,-5 \mathrm{cM}$ proximal to $C c k b r$, to Rbtn1, which lies $\sim 4 \mathrm{cM}$ distal to Cckbr. The close linkage between $H b b$ and $C c k b r$ in the mouse is also observed in the human. The human $\mathrm{CCK}_{\mathrm{B}}$ receptor gene was mapped to human $\mathrm{Chr} 11$ by analysis of a somatic cell hybrid mapping panel (Pisegna et al. 1992 ), and regional localization to $\mathrm{Chr} 11 \mathrm{p} 15$, near the $\beta$-hemo- 


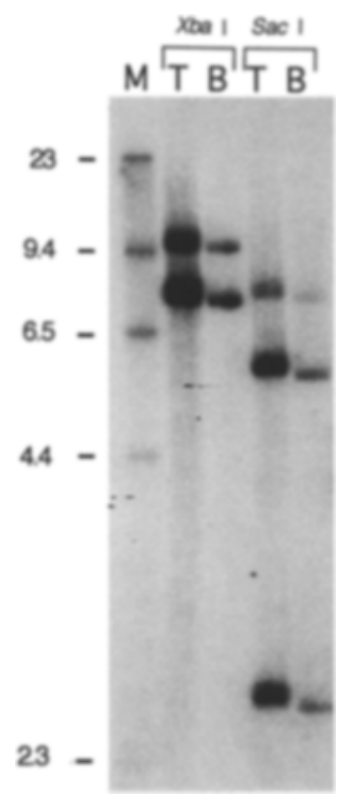

Fig. 4. The $\mathrm{CCK}_{\mathrm{B}}$ receptor gene is not grossly altered in $t u b / t u b$ mice. The Southern hybridization patterns of obese tub/tub (T) and C57BL/6J (B) genomic DNA were identical after digestion with ten different restriction enzymes and hybridization with a full-length $\mathrm{CCK}_{\mathrm{B}}$ receptor $\mathrm{CDNA}$ probe. Results from $X b a \mathrm{I}$ and SacI digestion are shown (BamHI, EcoRI, HindIII, $K p n \mathrm{I}, P s t \mathrm{I}, P v u \mathrm{I}, \mathrm{ScaI}$, and $\mathrm{XhoI}$ digests gave similar results and are not shown). The relative intensity differences between the $\mathrm{T}$ and $\mathrm{B}$ lanes are due to unequal loading and not to differences in $C c k b r$ copy number. The sizes $(\mathrm{kb})$ of the molecular weight standard $\lambda \times$ HindIII $(\mathrm{M})$ are indicated on the left.

globin locus, was demonstrated by fluorescence in situ hybridization (Song et al. 1993; Zimonjic et al. 1994).

Of particular interest is our localization of the $\mathrm{CCK}_{\mathrm{B}}$ receptor gene in the region of the tubby obesity mutation. Described in 1990 as a spontaneously arising mutation in a C57BL/6J male at The Jackson Laboratory, tubby is a recessive mutation producing a slowly developing obesity syndrome (Coleman and Eicher 1990). The body weight of mutant males 6 months of age is approximately $60 \%$ greater than that of normal mice. Mild hypoglycemia and hyperinsulinemia develop as $t u b / t u b$ animals mature. The tub mutation was previously mapped $2.4 \pm 1.4 \mathrm{cM}$ from $H b b$ (Jones et al. 1992). The backcross we analyzed showed no recombinants between $D 7 M i t 37(H b b)$ and $C c k b r$, resulting in a calculated maximum genetic distance between these genes of $3.1 \mathrm{cM}$, at the $95 \%$ confidence level (see Methods). Thus, the available mapping data indicate that $C c k b r$ and $t u b$ map to the same region (Fig. $3 \mathrm{~B})$. This identifies the $\mathrm{CCK}_{\mathrm{B}}$ receptor as a possible candidate gene for this obesity mutation. However, Southern analysis demonstrated that the $\mathrm{CCK}_{\mathrm{B}}$ receptor gene is not grossly altered in tubby mice. Further mapping studies utilizing tubby mouse crosses are needed to determine the genetic relationship between the $\mathrm{CCK}_{\mathrm{B}}$ receptor gene and this interesting obesity mutation.

The hypothesis that tubby results from a mutation in the $\mathrm{CCK}_{\mathrm{B}}$ receptor gene is compelling because of the well-characterized effects of CCK to modify feeding behavior. A satiety response after peripheral administration of exogenous CCK has been observed in a variety of mammalian species, including mice and humans (reviewed in Gibbs and Smith 1986). Intraperitoneal injection of CCK results in a dose-related reduction in both solid and liquid food intakes (Gibbs et al. 1973). The inhibition of a satiety response after vagotomy suggests the involvement of vagal afferent fibers in transmitting the systemic CCK signal to the brain (Smith et al. 1985). CCK release from neurons in the brain may also modulate feeding behavior, since intracerebroventricular infusion of CCK has been demonstrated to evoke satiety responses (DellaFera and Baile 1979; Baile et al. 1986). The specific CCK receptor type that mediates the satiety effect has not yet been clearly demonstrated. Evidence for both $\mathrm{CCK}_{\mathrm{A}}$ and $\mathrm{CCK}_{\mathrm{B}}$ receptor involvement has been obtained from numerous feeding behavior studies with specific receptor antagonists (Silver et al. 1989; Cooper and Dourish 1990; Weatherford et al. 1992; Moran et al. 1992; Schick et al. 1994). Analysis of the satiety response of CCK peptides and the molecular properties of $C C K$ receptors in $t u b / t u b$ mice may provide evidence for involvement of CCK pathways in the obesity phenotype exhibited by these mice.

Acknowledgments. We thank. Dr. Stephen Wank for providing CCK receptor cDNA clones, Drs. Sally Camper and Marion Buckwalter for helpful discussions and mouse genomic DNAs, and Lisa Swanberg for technical assistance. This research was supported by University of Michigan Gastrointestinal Peptide Center and Michigan Memorial-Phoenix Research Awards to L.C. Samuelson. K.A. Lacourse was supported by the Cellular and Molecular Approaches to Systems and Integrative Biology Training Grant from the National Institutes of Health (5T32GM08322).

\section{References}

Baile, C.A., McLaughlin, C.L., Della-Fera, M.A. (1986). Role of cholecystokinin and opioid peptides in control of food intake. Physiol. Rev. $66,172-234$.

Coleman, D.L., Eicher, E.M. (1990). Fat $(f a t)$ and tubby (tub): two autosomal recessive mutations causing obesity syndromes in the mouse. J. Hered. 81, 424-427.

Cooper, S.J., Dourish, C.T. (1990). Multiple cholecystokinin (CCK) receptors and CCK-monamine interactions are instrumental in the control of feeding. Physiol. Behav. 48, 849-857.

Della-Fera, M.A., Baile, C.A. (1979). Cholecystokinin octapeptidecontinuous picomole injection in the cerebral ventricles of sheep suppress feeding. Science 206, 471-473.

de Weerth, A., Pisegna, J.R., Huppi, K., Wank, S.A. (1993). Molecular cloning, functional expression and chromosomal localization of the human cholecystokinin type A receptor. Biochem. Biophys. Res. Commun. 194, 811-818.

Dietrich, W.R., Miller, J.C., Steen, R.G., Merchant, M., Damron, D., Nahf, R., Gross, A., Joyce, D.C., Wessel, M., Dredge, R.D., Marquis, A., Stein, L.D., Goodman, N., Page, D.C., Lander, E.S. (1994). A genetic map of the mouse with 4,006 simple sequence length polymorphisms. Nature Genet. 7, 220-245.

Dizik, M., Elliott, R.W. (1977). A gene apparently determining the extent of sialylation of lysosomal $\alpha$-mannosidase in mouse liver. Biochem. Genet. 15, 31-46.

Dourish, C.T., O'Neill, M.F., Coughlan, J., Kitchener, S.J., Hawley, D., Iversen, S.D. (1990). The selective CCK-B receptor antagonist L-365,260 enhances morphine analgesia and ptevents morphine tolerance in the rat. Eur. J. Pharmacol. 176, 35-44.

Feinberg, A.P., Vogelstein, B. (1983). A technique for radiolabeling DNA restriction endonuclease fragments to high specific activity. Anal. Biochem. 132, 6-13.

Friedman, J.M., Leibel, R.L., Bahary, N. (1991). Molecular mapping of obesity genes. Mamm. Genome 1, 130-144.

Gibbs, J., Smith, G.P. (1986). Gut peptides and feeding behavior: the model of cholecystokinin. in Feeding Behavior Neural and Humoral Controls, R.C. Ritter, S. Ritter, C.D. Barnes, eds. (New York: Academic Press), pp. 329-352.

Gibbs, J., Young, R.C., Smith, G.P. (1973). Cholecystokinin decreases food intake in rats. J. Comp. Physiol. Psychol. 84, 488-495.

Holdener, B.C., Brown, S.D.M., Angel, J.M., Nicholls, R.D., Kelsey, G., Magnuson, T. (1993). Mouse Chromosome 7. Mamm. Genome 4 (suppl.), S110-S120.

Hughes, J., Boden, P., Costall, B., Domeney, A., Kelly, E., Horwell, D.C., Hunter, J.C., Pinnock, R.D., Woodruff, G.N. (1990). Development of a class of selective cholecystokinin type B receptor antagonists having potent anxiolytic activity. Proc. Natl. Acad. Sci. USA 87, 6728-6732.

Innis, R.B., Snyder, S.H. (1980). Distinct cholecystokinin receptors in brain and pancreas. Proc. Natl. Acad. Sci. USA 77, 6917-6921.

Jenson, R.T., Wank, S.A., Rowley, W.H., Sato, S., Gardner, J.D. (1989). 
Interaction of CCK with pancreatic acinar cells. Trends Pharmacol. Sci. $10,418-423$.

Jones, J.M., Meisler, M.H., Seldin, M.F., Lee, B.K., Eicher, E.M. (1992). Localization of insulin-2 (Ins-2) and the obesity mutant tubby ( $t u b)$ to distinct regions of mouse chromosome 7. Genomics 14, 197-199.

Kopin, A.S., Lee, Y.-M., McBride, E.W., Miller, L.J., Lu, M., Lin, H.Y., Kolakowski, L.F., Beinborn, M. (1992). Expression cloning and characterization of the canine parietal cell gastrin receptor. Proc. Natl. Acad. Sci. USA 89, 3605 3609.

Kozak, C.A., Stephenson, D.A. (1993). Mouse Chromosome 5. Mamm. Genome 4 (Suppl.), S72-S87.

Lee, Y.M., Beinborn, M., McBride, E.W., Lu, M., Kolakowski Jr., L.F., Kopin, A.S. (1993). The human brain cholecystokinin-B/gastrin receptor. J. Biol. Chem. 268, 8164-8169.

Moran, T.H., Amegloi, P.J., Schwartz, G.J., McHugh, P.R. (1992). Blockage of type $A$, not type $B, C C K$ receptors attenuates satiety actions of exogenous and endogenous CCK. Am. J. Physiol. 262, R46-R50.

Nakata, H., Matsui, T., Ito, M., Taniguchi, T., Naribayashi, Y., Arima, N., Nakamura, A., Kinoshita, Y., Chihara, K., Hosoda, S., Chiba, T. (1992). Cloning and characterization of gastrin receptor from ECL carcinoid tumor of Mastomys natalensis. Biochem. Biophys. Res. Commun. 187, 1151-1157.

Pisegna, J.R., de Weerth, A., Huppi, K., Wank, S.A. (1992). Molecular cloning of the human brain and gastric cholecystokinin receptor: structure, functional expression and chromosomal location. Biochem. Biophys. Res. Commun. 189, 296-303.

Rowe, L.B., Nadeau, J.H., Turner, R., Frankel, W.N., Letts, V.A., Eppig, J.T., Ko, M.S.H., Thurston, S.J., Birkenmeier, E.H. (1994). Maps from two interspecific backcross DNA panels available as a community genetic mapping resource. Mamm. Genome 5, 253-274.

Schick, R.R., Schusdziarra, V., Yaksh, T.L., Go, V.L.W. (1994). Brain regions where cholecystokinin exerts its effect on satiety. Ann. N.Y. Acad. Sci. 713, 242-254.

Silver, A.J., Flood, J.F., Song, A.M., Morley, J.E. (1989). Evidence for a physiological role for CCK in the regulation of food intake in mice. Am. J. Physiol. 256, R646-R652.

Singh, L., Lewis, A.S., Field, M.J., Hughes, J., Woodruff, G.N. (1991). Evidence for an involvement of the brain cholecystokinin B receptor in anxiety. Proc. Natl. Acad. Sci. USA 88, 1130-1133.

Smith, G.P., Jerome, C., Norgue, R. (1985). Afferent axons in abdominal vagus mediate satiety effect of cholecystokinin in rats. Am. J. Physiol. 245, R638-R641.

Song, I., Brown, D.R., Wiltshire, R.N., Gantz, I., Trent, J.M., Yamada, T. (1993). The human gastrin/cholecystokinin type B receptor gene: alternative splice donor site in exon 4 generates two variant mRNAs. Proc. Natl. Acad. Sci. USA 90, 9085-9089.

Ulrich, C.D., Ferber, I., Holicky, E., Hadac, E., Buell, G., Miller, L.J. (1993). Molecular cloning and functional expression of the human gallbladder cholecystokinin A receptor. Biochem. Biophys. Res. Commun. 193, $204-211$.

Wank, S.A., Harkins, R., Jensen, R.T., Shapira, H., de Weerth, A., Stattery, T. (1992a). Purification, molecular cloning, and functional expression of the cholecystokinin receptor from rat pancreas. Proc. Natl. Acad. Sci. USA 89, 3125-3129.

Wank, S.A., Pisegna, J.R., de Weerth, A. (1992b). Brain and gastrointestinal cholecystokinin receptor family: structure and functional expression. Proc. Natl. Acad. Sci. USA 89, 8691-8695.

Weatherford, S.C., Chiruzzo, R.Y., Laughton, W.B. (1992). Satiety induced by endogenous and exogenous cholecystokinin is mediated by CCK-A receptors in mice. Am. J. Physiol. 262, R574-R578.

Wiesenfeld-Hallin, Z., Xu, X.-J., Hughes, J., Horwell, D.C., Hokfelt, T. (1990). PD134308, a selective antagonist of cholecystokinin type B receptor, enhances the analgesic effect of morphine and synergistically interacts with intrathecal galanin to depress spinal nociceptive reflexes. Proc. Natl. Acad. Sci. USA 87, 7105-7109.

Zimonjic, D.B., Popescu, N.C., Matsui, T., Ito, M., Chihara, K. (1994). Localization of the human cholecystokinin-B/gastrin receptor gene (CCKBR) to Chromosome 11p15.5-p15.4 by fluorescence in situ hybridization. Cytogenet. Cell Genet. 65, 184-185. 